\title{
胃十二指腸球部温存十二指腸切除術後の胃内外分泌機能 に関する実験的検討
}

\author{
順天堂大学医学部外科学第 1 教室（主任：柳原 宣教授) \\ 小 野 精 一
}

膵頭十二指腸切除術の合併症の 1 つである吻合部潰晹の成因を究明するために, 胃十二指腸球部温 存十二指腸切除術 (以下温存術) 後の胃内外分泌能が十二指腸球部温存の範囲によってどのよらに変 化するかを実験的に検討した。温存術後の基礎酸分泌量, 最高酸分泌量および insulin 刺激時の酸分泌 量は, 十二指腸球部温存範囲 $1 \mathrm{~cm}$ で $216.7 \%, 50.3 \%, 108.5 \%$ と著明な増加率を示したのに対し，十 二指腸球部温存範囲 $3 \mathrm{~cm}$ ではそれぞれ $5.5 \%, 3.0 \%, 1.9 \%$ の゙くずかな増加率であり, 十二指腸球 部の温存範囲が大きいものほど, 増加率は低かった。 また, secretinは幽門輪より $2 \mathrm{~cm} か ら 10 \mathrm{~cm}$ 遠位 に高濃度に分布していた。 以上の成績より, 術後の酸分泌増加は, duodenal brake の破綰によること が示唆された。 また，十二指腸温存範囲 $3 \mathrm{~cm}$ で術後生理的な胃内外分泌機能を示し，この温存範囲で 術後吻合部潰湢の発生を十分予防しえることが可能であることがわかった，

Key words : duodenectomy with preservation of the stomach and duodenal bulb, gastric functions, stomal ulcer, secretin in the duodenal and small intestinal mucosa

\section{I. 緒 言}

膵頭十二指腸切除 (pancreatoduodenectomy :

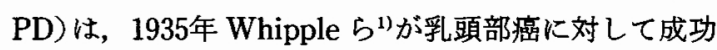
したのが最初である.彼らは幽門輪とともに全胃を温 存し切離した後, この胃側切離端を閉鎖, 胃体部で胃 空腸吻合を側々吻合にて結腸前で行い, 病巣切除は二 期的になされている。ついで，膵頭部癌に対して1937 年 Brunschwig ${ }^{2)}$ が二期的に病巣切除を行っているが, この術式においても胃は温存されている，1940年に入

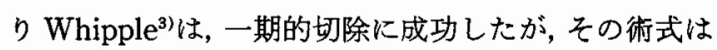
膵頭部, 十二指腸とともに胃の幽門側 $1 / 3 か ゙$ 合併切除さ れている。このように全胃温存で始まった術式である が，一転して小範囲胃切除術が行われるようになり， この方法が普及していった。しかし手術例が増加する につれて, 術後早期に空腸に吻合部潰場が発生すると いう報告 ${ }^{4) 5}$ が多くなされるようになった。吻合部潰瘍 の発生を予防あるいは減少させる方法として, 広範囲 胃切除術や，全幹迷走神経切離術 (truncal vagotomy; TV)が行われるよらになった. Warren ${ }^{6}$ は $65 \%$ の胃切 除術, あるいは小範囲(幽門部)胃切除術兼 TV を行っ

$<1990$ 年 2 月14日受理 $>$ 別刷請求先：小野 精一 7113 文京区本郷 2-1-1 順天堂大学第 1 外科
て潰瘍の発生を $17 \%$ から $7.5 \%$ に減少させることに成 功した. その後, PDに広範囲胃切除術を行うことは常 識となり，本邦でもこの術式が何ら抵抗なく受け入れ られてきた。

1978年 Traverso \& Longmire ${ }^{7}$ は術後の臟器相関 機能を維持し, 消化吸収障害抽よび萃機能不全を軽微 にとどめる目的で，幽門括約筋と迷走神経幽門枝を含 む全胃をともに温存し，から幽門輪より $4 \mathrm{~cm}$ 遠位の十 二指腸を残存した術式を 2 症例に行い報告した。その 後, 彼 ${ }^{8)}$ は慢性膵炎と傍乳頭部癌18例に本術式を行 い, その術後成績に関して，体重减少や食後早期腹部 症状などの発生頻度は少なく, 酸分泌も高酸例はなく 吻合部潰煬の発生もなかったと報告している。以来, いくつかの施設9) 24)で本術式が追試, 検討され, 良好 な術後経過の報告がなされている。しかし, 高酸例で

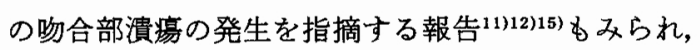
いまだ確立された術式であるとはいえない。

そこで，十二指腸切除術後の胃内外分泌機能が十二 指腸球部の温存範囲にどのように影響されるかを検討 し，さらに十二指腸・小腸粘膜内の gastrin および secretinの分布を実験的に調べることにより，十二指腸 球部の温存範囲を検討したので報告する. 


\section{II. 研究対象ならひに研究方法}

1. 研究対象

研究対象は, 体重14～18kg の雌雄雑種成犬18頭であ る. 実験群は十二指腸球部温存 $1 \mathrm{~cm}$ (単に $1 \mathrm{~cm}$ 群), 2 $\mathrm{cm}$ 群， $3 \mathrm{~cm}$ 群执よび secretin, gastrin 分布検討群の 4 群とし, 前 3 群は各 5 頭で, 最後の群は 3 頭で検討 した.

2. 研究方法

1）全胃瘦犬作成方法

イヌを pentobarbital $25 \mathrm{mg} / \mathrm{kg}$ で麻酔後, 上腹部正 中切開にて開腹，胃体部大彎側前壁にイヌ用 Thomas 型金属カニューレ（夏目製作所）を㨀入後左上腹部の 皮唐に固定し，全胃瘦犬を作成した。手術終了後 3 週 以降に検查を開始した。

2）胃十二指腸球部温存十二指腸切除術

術前検查終了後の全胃瘻犬を用いて，胃十二指腸球 部温存十二指腸切除術（以下温存術）を施行した。

十二指腸の切除範囲は, 幽門輪より遠位 $1 \mathrm{~cm}, 2 \mathrm{~cm}$ お よび3cm の部より Treitz 靯帯までの十二指腸とし， 释合部はさらにそれぞれ遠位 $0.5 \mathrm{~cm}$ とした（Fig. 1 -a).

手術は背側膵管 (副膵管) ・腹側膵管 (膵管) 切離, 総胆管切離, 十二指腸切離，再建の順で行った。総胆 管拉よび十二指腸処理の際には，血管，結合組織の剥
離に細心の注意を払い，迷走神経幽門枝の損傷を防い だ。すず，十二指腸の膵臓付着部の遠位より十二指腸 を剥離, 背側膵管と腹側膵管を露出した後, 背側膵管 を切離し, 内径 $0.6 \mathrm{~mm}$, 外径 $1.0 \mathrm{~mm}$ の stent tubeを 挿入後, 膵液の流出を確認し固定した。また，腹側膵 管はそのまま結禁切離した。 さらに十二指腸を近位側 に剶離し総胆管を露出, 十二指腸入口部近くで切離し, 内径 $1.2 \mathrm{~mm}$, 外径 $2.0 \mathrm{~mm}$ の stent tube を挿入後, 胆 汁の流出を確認し固定した。そして，最後に十二指腸 温存範囲を正確に測定し，十二指腸切離を行った。再 建は, 空腸断端部を盲端とし, 膵管空腸端側吻合 (層々 二層縫合)，十二指腸空腸端側吻合 (Gambee一層縫 合)，総胆管空腸端側吻合 (全層一層縫合)の願に行っ た（Fig. 1-b).

温存術後 3 週目以降に術前と同一の諸検査を施行し た。

3）術前，術後検查項目

(1) 胃外分泌機能検査

A，胃液採取法ならびに胃液測定法

胃液検查は，検査開始24時間前より絶食とし，Pavlov standにイヌを固定後, カニューレより胃内を約 $37^{\circ} \mathrm{C}$ の生理食塩水で十分に洗净し，30分間放置した後 行った。胃液採取は, 刺激開始 1 時間前に行い, 刺激 開始後15分ごとに 2 時間目まで行った。採取した胃液

Fig. 1 Operative method for duodenectomy preserving the stomach and duodenal bulb

a)

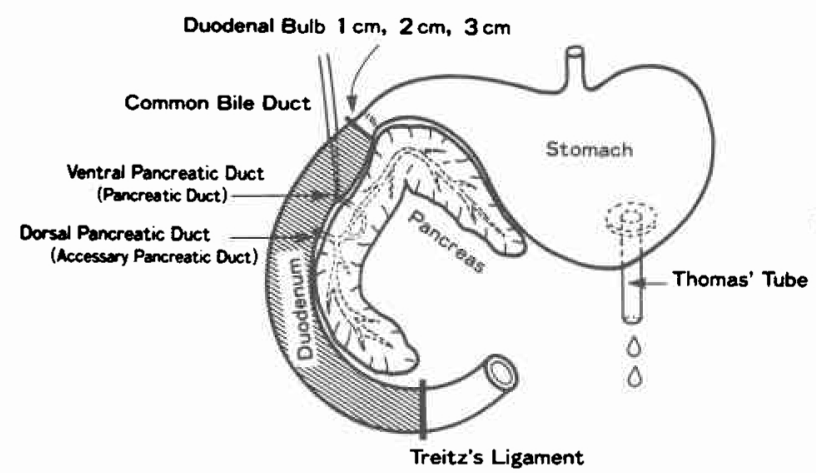

Range of Resection: The shaded portion indicates an area of resection. The duodenal portions from distal points 1,2 and $3 \mathrm{~cm}$ removed from the pyloric ring to Treitz's ligament b)

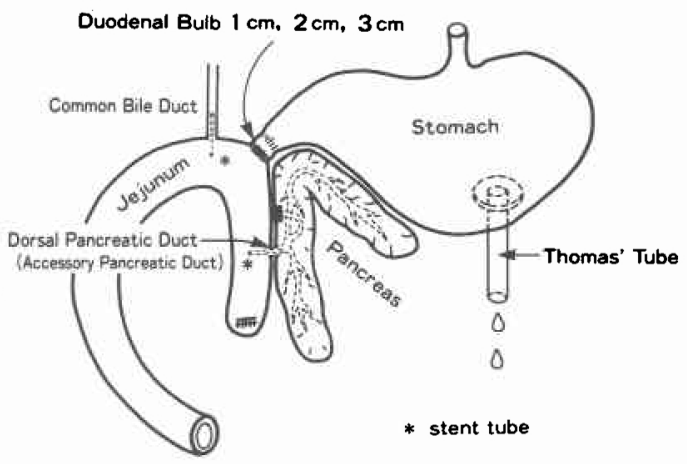

Method of Reconstruction:

The jejunal stump was left as a blind end, and end-to-side anastomosis to the jejunum was performed in the order of the pancreas, duodenum stump and common bile duct. The ventral pancreatic duct was ligated, and a stent tube was inserted into the dorsal pancreatic duct and common bile duct. 
は，東垔電波工業社製 $\mathrm{pH}$ TITRATOR MODEL STOMA-1を用い, $\mathrm{pH}$ を測定後, $1 \mathrm{ml}$ を0.1N NaOH にて pH 7.00 まで連続滴定し，胃液量を乗じて酸分泌 量を求めた。

\section{B. 基礎酸分泌量}

刺激開始前 1 時間の胃酸分泌量を basal acid output（以下 BAO: $\mathrm{mEq} / \mathrm{hr}$ ）として表わした。

\section{Tetragastrin 刺激時の酸分泌量}

Tetragastrin 刺激は $4 \mathrm{mg} / \mathrm{kg} / \mathrm{hr}$ で 2 時間行い, 刺 激開始後 1 時間の胃酸分泌量を maximal acid output （以下 $\mathrm{MAO}: \mathrm{mEq} / \mathrm{hr}$ ）として表わした.

D. Insulin 低血糖刺激時の酸分泌量

Regular insulin $2 \mathrm{u} / \mathrm{kg}$ を生理食塩水 $20 \mathrm{ml}$ にとかし て静脈内に投与した後, 胃液採取を 2 時間施行し, そ の30分目から90分目までの 1 時間の胃酸分泌量を insulin 低血糖刺激後の acid output (以下 IAO : mEq) hr）として表わした.

(2) 胃内分泌機能検查

A. 血清 gastrin

a 、血清 gastrin 値測定法ならびに採血法

血清 gastrin 值の測定は，ミドリ十字社製 gastrin ${ }^{125}$ I-kit を用い，2 抗体法による radioimmunoassay 法で測定し, 試薬の調整执よび操作は kit 付属の説明 書にしたがった。ただし，標準母液の希釈は21.0pg $/ \mathrm{ml}$ まで行い，標準曲線を作成した，な括採血は刺激開始 30 分前より 15 分ごとに 2 時間目まで末梢静脈に留置し たカニニーレより行った。

b. 空腹時血清 gastrin 值 (basal gastrin 以下 BG : $\mathrm{pg} / \mathrm{ml}$ )

BG は刺激開始 30 分前より 15 分ごと 2 回測定し，こ の 2 回の平均值より算出した.

c. Insulin 低血糖刺激後の gastrin 分泌反応 (insulin integrated gastrin response 以下 I-IGR : $\mathrm{ng} \cdot \mathrm{min} /$ $\mathrm{ml}$ )

I-IGR は insulin $2 \mathrm{u} / \mathrm{kg}$ 刺激後 15 分ごとに 2 時間目 まで血清 gastrin 值を測定し，その30分目から90分目 までの 1 時間の值で，BG より高值を示した各分画の 総和により算出した。

d。肉汁ェキス刺激後の gastrin 分泌反応（test meal integrated gastrin response 以下 T-IGR: ng• $\mathrm{min} / \mathrm{ml}$ )

T-IGR は肉汁エキス刺激時の血清 gastrin 值を，刺 激後 15 分ごとに 2 時間目まで測定し，刺激開始後 60 分 目までの 1 時間の值で, $B G$ 上り高値を示した各分画
の総和により算出した。な拉，肉汁ェキスは Campbell 社製「beef broth $1100 \mathrm{ml}$ を用いたが，その成分は，100 $\mathrm{ml}$ 中に蛋白質 $3.2 \mathrm{~g}$, 脂肪 $1.4 \mathrm{~g}$, 炭水化物 $4.4 \mathrm{~g}$ を含有し ている.

B. 血清 secretin

a . 血清 secretin 値測定法

血清 secretin 値の測定は, 第一 [secretin] RIA kit を用い，2 抗体法による radioimmunoassay 法で測定 し, 試薬の調整および操作は kit 付属の説明書にした がった. ただし，標準母液の希釈は $50 \mathrm{pg} / \mathrm{ml}$ まで行い, 標準曲線を作成した。

b. 空腹時血清 secretin 值 (basal secretin以下 $\mathrm{BS}: \mathrm{pg} / \mathrm{ml}$ )

BS は刺激開始30分前より15分ごとに 2 回測定し， この 2 回の平均値より算出した。

c. Insulin 低血糖刺激後の secretin 分泌反応 (insulin integrated secretin response 以下 I-ISR : ng• $\mathrm{min} / \mathrm{ml}$ )

I-ISR は insulin $2 \mathrm{u} / \mathrm{kg}$ 刺激後 15 分ごとに 2 時間目 まで血清 secretin 值を測定し，その30分目から90分目 までの 1 時間の値で, BSより高値を示した各分画の 総和により算出した。

d. 肉汁エキス刺激後の secretin 分泌反応（test meal integrated secretin response 以下 T-ISR : ng • $\mathrm{min} / \mathrm{ml}$ )

T-ISR は肉汁ェキス刺激時の血清 secretin 值を, 刺 激後 15 分ごとに 2 時間目まで測定し，刺激開始後 60 分 目までの 1 時間の值で，BSょり高値を示した各分画 の総和により算出した。

4）正常犬の十二指腸・小腸粘膜に抢ける gastrin と secretin の分布

正常犬の十二指腸おるよ゙少腸粘膜内に括ける secretin は，幽門輪より $5 \mathrm{~cm}$ 遠位までは $1 \mathrm{~cm}$ 間隔で，そ れより遠位は $10 \mathrm{~cm}$ 間隔で $120 \mathrm{~cm}$ まで測定し，gastrin は $20 \mathrm{~cm}$ まで測定した。

(1) 粘膜内含有量の測定

A. Gastrin：粘膜内 gastrin 含有量の測定は Berson $ら^{25}$ の方法に準じ, 粘膜組織 $100 \mathrm{mg}$ 湿重量に蒸留 水 $2 \mathrm{ml}$ 加之 20 分間煮沸した後, Swiss KINEMATICA 社製 POLYTORON 超高速 homogenizer で細切し, $4{ }^{\circ} \mathrm{C}, 10,000 \mathrm{rpm}$ で20分間遠 心分離して得られた上清を, $-20^{\circ} \mathrm{C}$ にて保存した。清 は室温で解凍した後, 血清 gastrin と同じょうに, ミド リ十字社製 gastrin ${ }^{125}$ I-kit を用いて測定した。 
B. Secretin：粘膜内 secretin含有量の測定は

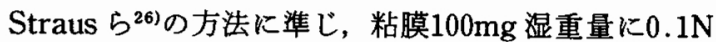
$\mathrm{HCl} 2 \mathrm{ml}$ と trazirol $1,000 \mathrm{u}$ を加えて細切し 3 分間煮 沸した後 $4{ }^{\circ} \mathrm{C}, 10,000 \mathrm{rpm}, 20$ 分間遠心分離して得られ た上清を凍結乾燥後 $-20^{\circ} \mathrm{C}$ にて保存した。凍結標本は, 第一「secretin」RIA kit 用の希釈剂にて溶解し測定し た.

\section{(2) 粘膜内細胞数の測定}

粘膜内 gastrin 招よび secretin 細胞数の測定は，粘 膜組織検体採取後直ちにZamboni 固定液に浸し， $4{ }^{\circ} \mathrm{C} に て 12$ 時間固定後パラフィン包埋し，ブロックを
作製後，薄切切片を用い行った。染色法は，非標識酵 素抗体法 (peroxidase antiperoxidase 法：以下 PAP 法)にて, DAKO 社の PAP kitで行った.な报, gastrin 抗血清は kit 付属の Rabbit antigastrin を, secretin 抗血清は国立がんセンター病院阿部薰副院長, 細胞増 殖因子研究部山口建部長より提出された NCC-R-1 ${ }^{27}$ を使用した。

細胞の測定は, gastrin 細胞, secretin 細胞ともに高 橋ら ${ }^{28)}$ の方法にしたがい，20倍の拡大対物レンズを用 い，接眼部に $10 \mathrm{~mm}$ 四方の目盛りのついた eye piece を装着しこれによって切片を粘膜筋板に垂直方向に

Table 1 Pre-and postoperative changes of BAO, MAO and IAO in groups with preservation of the duodenal bulb over a range of 1,2 and $3 \mathrm{~cm}$.

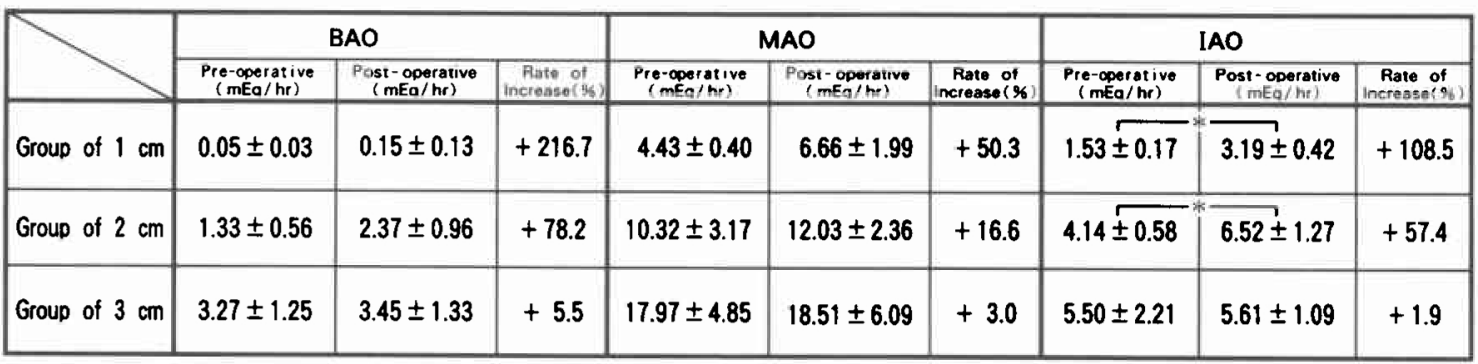

$M \pm S E \quad(n \neq 5)$

$* p<0.01$

Fig. 2 Pre-and postoperative changes of $\mathrm{BAO}, \mathrm{MAO}$ and IAO in groups with preservation of the duodenal bulb over a range of 1,2 and $3 \mathrm{~cm}$

〈BAO $n=5$

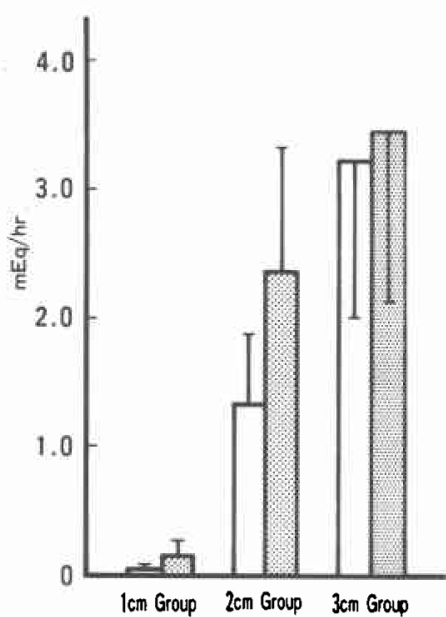

〈MAO〉 $n=5$

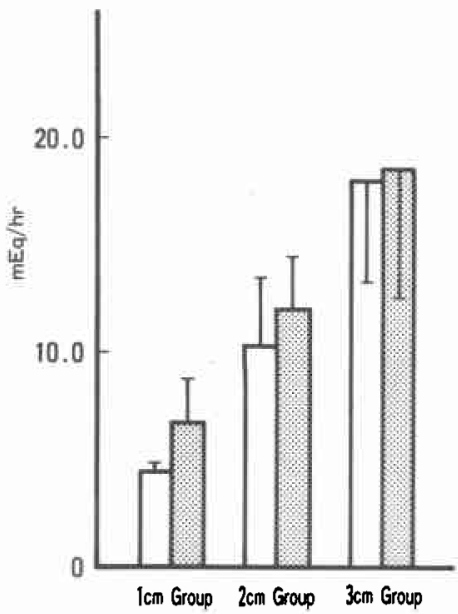

〈IAO

$n=5$

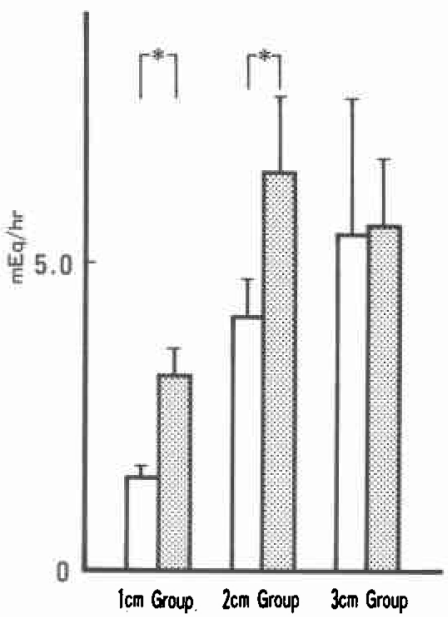

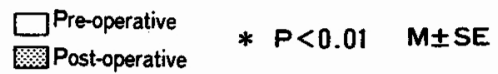


区分した区画のなかに含まれる細胞を数えて，これを 単位区画中の細胞数とした。 また, 細胞の算出は, 核 をむつ細胞のみを対象とし，30個の単位区画中の細胞 数を数えて平均値をだし，これを $\mathrm{mm}^{2} に$ 換算して粘膜 表面の単位面積あたりの細胞数とした.

5) 剖検

検査終了後, 温存手術を施行したすべてのイヌを屠 殺し，胃空腸吻合部の状態および残存十二指腸範囲の 確認などの肉眼的観察を行った。

6) 統計处理法
得られたデータは平均値士 $\mathrm{SE}$ で表わし，すべて $\mathrm{t}$ 検 定にて統計処理を行い, 危険率 (p) が $5 \%$ 以下 $(p<$ 0.05）を有意差ありと判定した。

\section{III. 成}

\section{1. 胃外分泌機能検査}

胃外分泌機能検查の結果は Table 1, Fig. 2 に示す と括りである。

1) 基礎酸分泌量 (BAO)

$\mathrm{BAO}$ は術前と比較して, 術後 $1 \mathrm{~cm}$ 群および $2 \mathrm{~cm}$ 群 で増加したが, $3 \mathrm{~cm}$ 群では術前術後でほとんど差が認

Table 2 Pre-and Postoperative changes of BG, T-IGR and I-IGR in groups with preservation of the duodenal bulb over a range of 1,2 and $3 \mathrm{~cm}$.

\begin{tabular}{|c|c|c|c|c|c|c|c|c|c|}
\hline & \multicolumn{3}{|c|}{ B.G } & \multicolumn{3}{|c|}{ T-IGR } & \multicolumn{3}{|c|}{ I-IGR } \\
\hline & $\begin{array}{c}\begin{array}{c}\text { Pro-operative } \\
\text { (pgisia) }\end{array} \\
\end{array}$ & $\begin{array}{c}\text { Post - operative } \\
(\mathrm{pg} / \mathrm{m} t)\end{array}$ & $\begin{array}{c}\text { Rate of } \\
\text { increase (\%) }\end{array}$ & $\begin{array}{c}\text { Pre-operativo } \\
\text { (ng.einin/mil) }\end{array}$ & $\begin{array}{c}\text { Post-operative } \\
\text { (ng-ain/mI) }\end{array}$ & \begin{tabular}{|c|}
$\begin{array}{c}\text { Riate of } \\
\text { Increase(\%) }\end{array}$ \\
\end{tabular} & $\begin{array}{c}\text { Prre-operative } \\
\text { (nqmein/el) }\end{array}$ & $\begin{array}{c}\text { Post - operative } \\
(\mathrm{ng} \cdot \mathrm{min} / \mathrm{m})\end{array}$ & $\begin{array}{c}\text { Rate of } \\
\text { Increase (\%) }\end{array}$ \\
\hline Group of $1 \mathrm{~cm}$ & $18.7 \pm 2.7$ & $25.3 \pm 2.5$ & +35.3 & $0.92 \pm 0.22$ & $1.53 \pm 0.20$ & +65.3 & $1.67 \pm 0.61$ & $2.89 \pm 1.34$ & +73.1 \\
\hline Group of $2 \mathrm{~cm}$ & $40.9 \pm 4.0$ & $42.4 \pm 2.4$ & +3.7 & $0.87 \pm 0.41$ & $1.22 \pm 0.30$ & +40.0 & $1.22 \pm 0.31$ & $\overline{2.12} \pm 0.69$ & +74.1 \\
\hline Group of $3 \mathrm{~cm}$ & $26.9 \pm 2.6$ & $33.4 \pm 2.4$ & +24.2 & $0.78 \pm 0.34$ & $1.06 \pm 0.33$ & +36.0 & $1.61 \pm 0.43$ & $1.65 \pm 0.59$ & +2.6 \\
\hline & & & & & & $M=$ & $\begin{array}{c}(n=5) \\
* p<0.0 \\
* * p<0.0\end{array}$ & & \\
\hline
\end{tabular}

Fig. 3 Pre-and postoperative changes of BG, T-IGR and I-IGR in groups with preservation of the duodenal bulb over a range of 1,2 and $3 \mathrm{~cm}$.

$\langle\mathbf{B} \mathbf{G}\rangle$

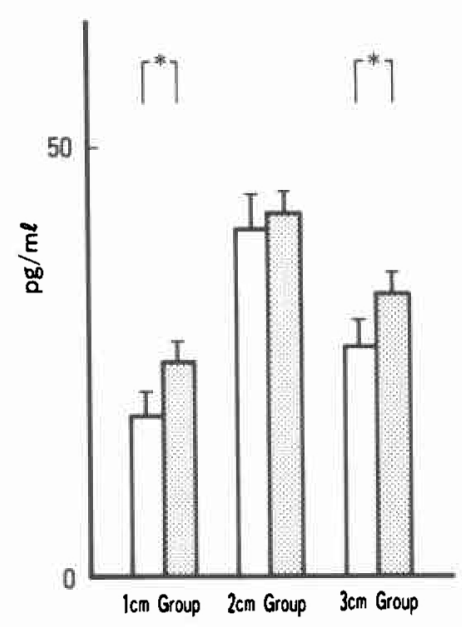

(T-IGR) $n=5$
〈I-IGR〉 $n=5$
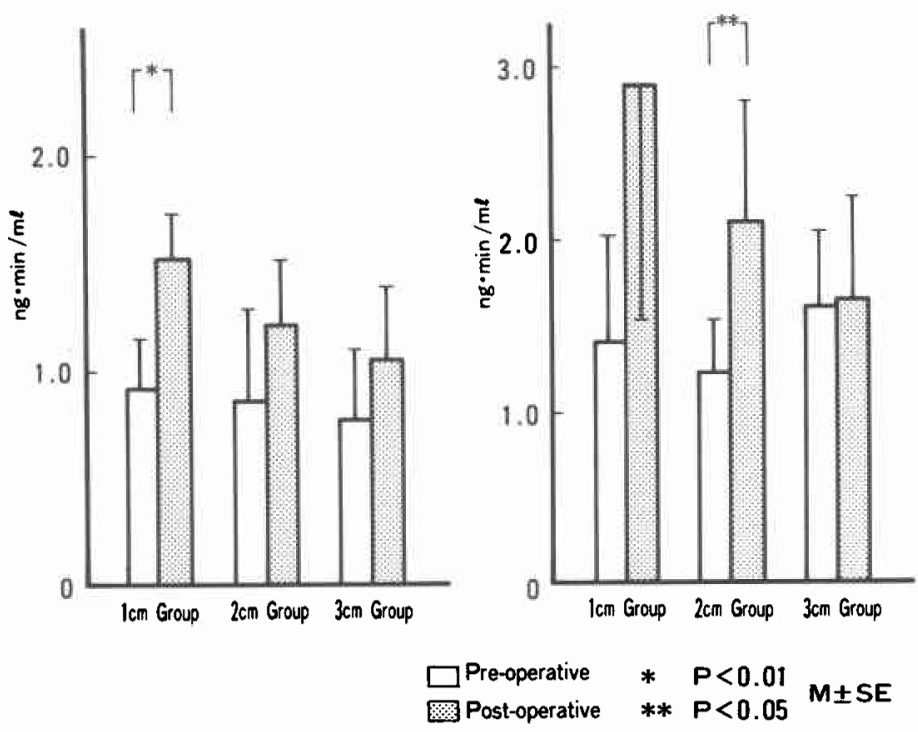
められなかった。これを術後の増加率でみてみると， $1 \mathrm{~cm}$ 群で約 3 倍, $2 \mathrm{~cm}$ 群で約 2 倍であった。

2) Tetragastrin 刺激時の最高酸分泌量 (MAO)

$\mathrm{MAO}$ は術前と比較して, 術後 $1 \mathrm{~cm}$ 群で $4.43 \pm 0.40$ $\mathrm{mEq} / \mathrm{hr}$ から6.66 $1.99 \mathrm{mEq} / \mathrm{hr}$ と増加傾向 $(\mathrm{p}<0.1)$ を示したが， $2 \mathrm{~cm}$ 群では軽度の增加がみられ， $3 \mathrm{~cm}$ 群 では術前術後でほとんど差が認められなかった。術後 の増加率は, $1 \mathrm{~cm}$ 群で $50.3 \%, 2 \mathrm{~cm}$ 群で $16.6 \%, 3 \mathrm{~cm}$ 群で3.0\%であった。

3) Insulin 低血糖刺激時の酸分泌量（IAO）

IAO は術前と比較して術後は, $1 \mathrm{~cm}$ 群で $1.53 \pm 0.17$
$\mathrm{mEq} / \mathrm{hr}$ から $3.19 \pm 0.42 \mathrm{mEq} / \mathrm{hr}, 2 \mathrm{~cm}$ 群で $4.14 \pm$ $0.58 \mathrm{mEq} / \mathrm{hr}$ から6.52 $1.27 \mathrm{mEq} / \mathrm{hr}$ とともに術後有 意 $(\mathrm{p}<0.01)$ に増加したが, $3 \mathrm{~cm}$ 群は術前術後でほと んど差がみられなかった。これを術後の増加率でみて みると, $1 \mathrm{~cm}$ 群で108.5\%, $2 \mathrm{~cm}$ 群で57.4\%, $3 \mathrm{~cm}$ 群で 1.9\%であった。

2. 胃内分泌機能検査

胃内分泌機能検查の gastrinの結果は, Table 2, Fig. 3 に, secretin の結果は Table 3, Fig. 4 に示す とおりである。

1）血清 gastrin

Table 3 Pre-and postoperative changes of BS, T-ISR and I-ISR in groups with preservation of the duodenal bulb over a range of 1,2 and $3 \mathrm{~cm}$.

\begin{tabular}{|c|c|c|c|c|c|c|c|c|c|}
\hline & \multicolumn{3}{|c|}{ B.S } & \multicolumn{3}{|c|}{$\mathrm{T}$ - ISR } & \multicolumn{3}{|c|}{ I - ISR } \\
\hline & $\begin{array}{c}\text { Pre-operat ive } \\
(\mathrm{pg} / \mathrm{mI})\end{array}$ & $\begin{array}{c}\text { Post-operative } \\
\text { (og/mI) }\end{array}$ & $\begin{array}{l}\text { Rate of increase } \\
\text { and denrease( } 90) \\
\end{array}$ & $\begin{array}{l}\text { Pre-coerative } \\
\text { [ng-thin/al) } \\
\end{array}$ & $\begin{array}{c}\begin{array}{c}\text { Post - operative } \\
(\mathrm{mg} \cdot \min / \mathrm{m} /)\end{array} \\
\end{array}$ & \begin{tabular}{|l}
$\begin{array}{l}\text { Rate of increase } \\
\text { and decreasects) }\end{array}$ \\
\end{tabular} & $\begin{array}{c}\text { Pre-operative } \\
\text { (nz"inin/ni) }\end{array}$ & $\begin{array}{c}\text { Post-operative } \\
\text { (ng-ninifint) }\end{array}$ & $\begin{array}{l}\text { Rate of increase } \\
\text { and deciesse ( } \% \text { ) } \\
\end{array}$ \\
\hline Group of $1 \mathrm{~cm}$ & $133.3 \pm 12.4$ & $765.8 \pm 19.1$ & +24.4 & $1.88 \pm 0.18$ & $2.04 \pm 0.32$ & +8.2 & $1.18 \pm 0.45$ & $2.76 \pm 0.46$ & +133.9 \\
\hline Group of $2 \mathrm{~cm}$ & $141.0 \pm 18.9$ & 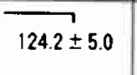 & -11.9 & $1.12 \pm 0.22$ & $1.52 \pm 0.44$ & +35.5 & $1.51 \pm 0.80$ & $1.71 \pm 0.12$ & +13.2 \\
\hline Group of $3 \mathrm{~cm}$ & $163.9 \pm 33.3$ & $\overline{112.2 \pm 14.4}$ & -31.5 & $1.89 \pm 0.51$ & $1.60 \pm 0.32$ & -15.3 & $1.23 \pm 0.34$ & $1.09 \pm 0.31$ & -11.3 \\
\hline & & & & & & & $\begin{array}{l}\text { ( } n=5 \\
* p<\end{array}$ & 0.01 & \\
\hline
\end{tabular}

Fig. 4 Pre-and postoperative changes of BS, T-ISR and I-ISR in Groups with preservation of the duodenal bulb over a range of 1,2 and $3 \mathrm{~cm}$.

〈B S > $n=5$

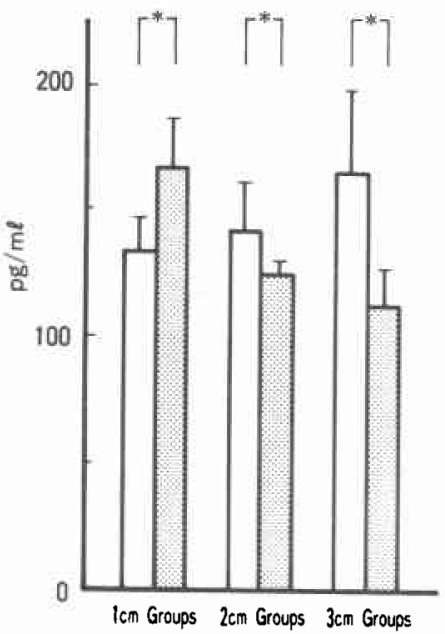

(T-ISR) $n=5$

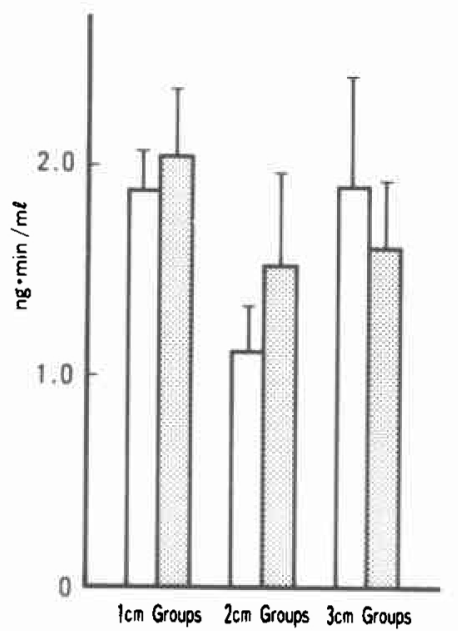

$\langle\mathbf{I}-\mathbf{S R}\rangle$

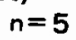

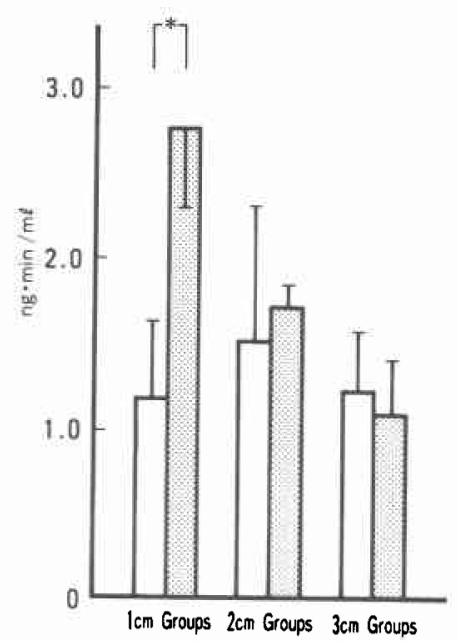

$\square$ Pre-operative Post-operative

$* P<0.01 \quad M \pm S E$ 
(1) 空腹時血清 gastrin 值 (BG)

BG は, $1 \mathrm{~cm}$ 群で $18.7 \pm 2.7 \mathrm{pg} / \mathrm{ml}$ から $25.3 \pm 2.5$ $\mathrm{pg} / \mathrm{ml}, 2 \mathrm{~cm}$ 群で $40.9 \pm 4.0 \mathrm{pg} / \mathrm{ml}$ から $42.4 \pm 2.4 \mathrm{pg} /$ $\mathrm{ml}, 3 \mathrm{~cm}$ 群で $26.9 \pm 2.6 \mathrm{pg} / \mathrm{ml}$ から $33.4 \pm 2.4 \mathrm{pg} / \mathrm{ml}$ と 術後各群で増加し, 特に $1 \mathrm{~cm}$ 群, $3 \mathrm{~cm}$ 群では有意 $(\mathrm{p}<$ $0.01)$ に増加した。術後の増加率は, $1 \mathrm{~cm}$ 群で $35.3 \%$, $2 \mathrm{~cm}$ 群で3.7\%, $3 \mathrm{~cm}$ 群で $24.2 \%$ の増加であった。

(2) 肉汁エキス刺激時の血清 gastrin 反応 (T-IGR)

術前の T-IGR は $1 \mathrm{~cm}$ 群で0.92 $0.22 \mathrm{ng} \cdot \mathrm{min} / \mathrm{ml}, 2$

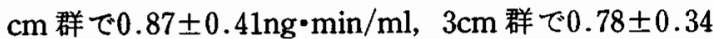
$\mathrm{ng} \cdot \mathrm{min} / \mathrm{ml}$ であり，術後の T-IGR はそれぞれ1.53士 $0.20 \mathrm{ng} \cdot \mathrm{min} / \mathrm{ml}, 1.22 \pm 0.30 \mathrm{ng} \cdot \mathrm{min} / \mathrm{ml}, 1.06 \pm 0.33$ $\mathrm{ng} \cdot \mathrm{min} / \mathrm{ml}$ といずれる術前より増加しており，ことに $1 \mathrm{~cm}$ 群では有意の増加がみられた。術後の増加率はそ

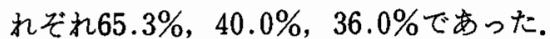

(3) Insulin 低血糖刺激時 $の$ 血清 gastrin 反応（IIGR)

術前, 術後の I-IGR は $1 \mathrm{~cm}$ 群で $1.67 \pm 0.61 \mathrm{ng} \cdot \mathrm{min} /$ $\mathrm{ml}, 2.89 \pm 1.34 \mathrm{ng} \cdot \mathrm{min} / \mathrm{ml}, 2 \mathrm{~cm}$ 群で1.22 $\pm 0.31 \mathrm{ng} \cdot$ $\mathrm{min} / \mathrm{ml}, 2.12 \pm 0.69 \mathrm{ng} \cdot \mathrm{min} / \mathrm{ml}, 3 \mathrm{~cm}$ 群で $1.61 \pm 0.43$ $\mathrm{ng} \cdot \mathrm{min} / \mathrm{ml}, 1.65 \pm 0.59 \mathrm{ng} \cdot \mathrm{min} / \mathrm{ml}$ となり, $2 \mathrm{~cm}$ 群で 有意 $(\mathrm{p}<0.05)$ に增加した。術後の増加率はそれぞれ $73.1 \% ， 74.1 \% ， 2.6 \%$ であった。

2) 血清 secretin

(1) 空腹時血清 secretin 值 (BS)

術前後の BSは, $1 \mathrm{~cm}$ 群で $133.3 \pm 12.4 \mathrm{pg} / \mathrm{ml}$,
$165.8 \pm 19.1 \mathrm{pg} / \mathrm{ml}, 2 \mathrm{~cm}$ 群 で $141.0 \pm 18.9 \mathrm{pg} / \mathrm{ml}$, $124.2 \pm 5.0 \mathrm{pg} / \mathrm{ml}, 3 \mathrm{~cm}$ 群 で $163.9 \pm 33.3 \mathrm{pg} / \mathrm{ml}$, $112.2 \pm 14.4 \mathrm{pg} / \mathrm{ml}$ であった。術前値に対する術後値 の増減率は $1 \mathrm{~cm}$ 群で $24.4 \%$ と有意 $(\mathrm{p}<0.01)$ に増加し たが， $2 \mathrm{~cm}$ 群で $11.9 \% ， 3 \mathrm{~cm}$ 群で $31.5 \%$ と有意 $(\mathrm{p}<$ 0.01）に減少した。

(2) 肉汁エキス刺激時の血清 secretin 反応 (T-ISR) 術前の T-ISR は $1 \mathrm{~cm}$ 群で $1.88 \pm 0.18 \mathrm{ng} \cdot \mathrm{min} / \mathrm{ml}, 2$ $\mathrm{cm}$ 群で $1.12 \pm 0.22 \mathrm{ng} \cdot \mathrm{min} / \mathrm{ml}, 3 \mathrm{~cm}$ 群で1.89 0.51 $\mathrm{ng} \cdot \mathrm{min} / \mathrm{ml}$ であり，術後はそれぞれ2.04士0.32ng・ $\mathrm{min} / \mathrm{ml}, 1.52 \pm 0.44 \mathrm{ng} \cdot \mathrm{min} / \mathrm{ml}, 1.60 \pm 0.32 \mathrm{ng} \cdot \mathrm{min} /$ $\mathrm{ml}$ であった。術前值に対する術後値の増減率は, $1 \mathrm{~cm}$ 群で $8.2 \%, 2 \mathrm{~cm}$ 群で $35.5 \%$ と増加したが, $3 \mathrm{~cm}$ 群では 15.3\%減少した。

(3) Insulin 低血糖刺激時の血清 secretin 反応（IISR)

術前の I-ISR は $1 \mathrm{~cm}$ 群で $1.18 \pm 0.45 \mathrm{ng} \cdot \mathrm{min} / \mathrm{ml}, 2$

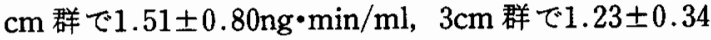
$\mathrm{ng} \cdot \mathrm{min} / \mathrm{ml}$ であり, 術後はそれぞれ2.76士0.46ng・ $\mathrm{min} / \mathrm{ml}, 1.71 \pm 0.12 \mathrm{ng} \cdot \mathrm{min} / \mathrm{ml}, 1.09 \pm 0.31 \mathrm{ng} \cdot \mathrm{min} /$ $\mathrm{ml}$ であった。これを術前値に対する術後値の増加率で みてみると， $1 \mathrm{~cm}$ 群で133.9\%，2cm 群で13.2\%増加 し, 特に $1 \mathrm{~cm}$ 群では有意 $(\mathrm{p}<0.01)$ の增加であったが, $3 \mathrm{~cm}$ 群では $11.3 \%$ 減少した。

3. 正常犬の十二指腸，小腸粘膜内 gastrin おょび secretinの分布

Fig. 5 Distribution of gastrin and secretin in the duodenal and small intestinal mucosa in normal dogs.
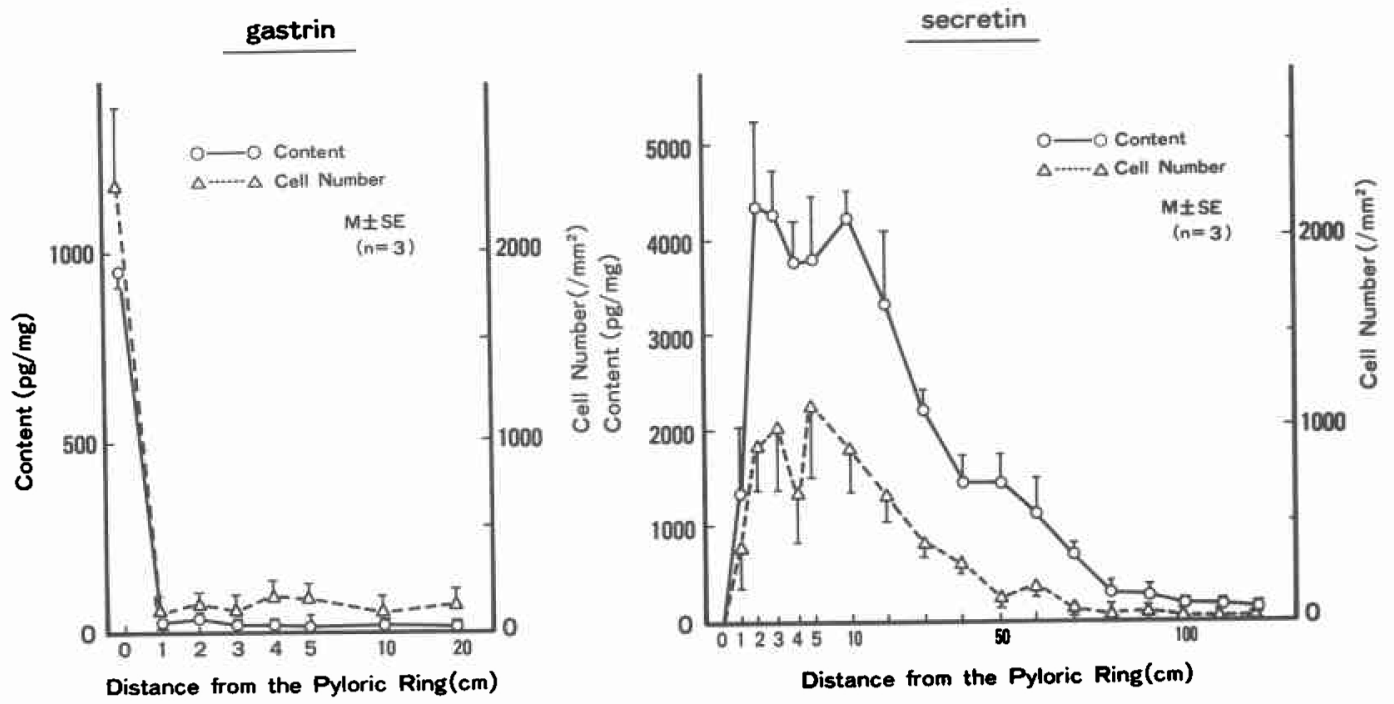
Fig. 6 Secretin cells in the duodenal bulb (PAP method, $\times 200$ )

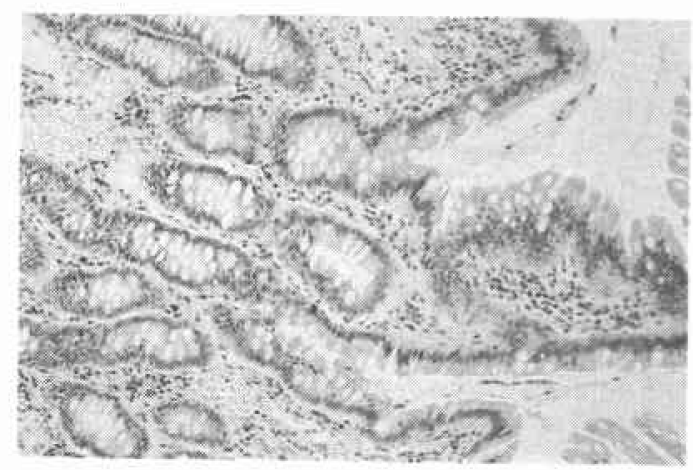

$1 \mathrm{~cm}$ from the Pyloric Ring

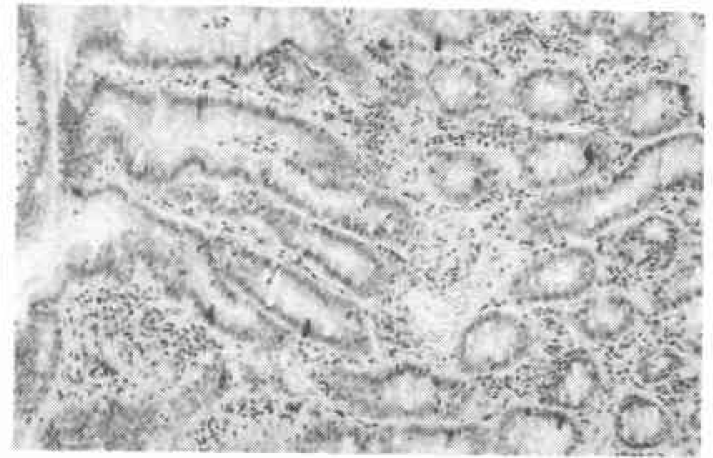

$3 \mathrm{~cm}$ from the Pyloric Ring
1) Gastrin の分布

(1) 粘膜内 gastrin 含有量

粘膜内 gastrin 含有量は幽門輪上で953.0土38.3pg/ $\mathrm{mg}$ と高值であったが, 幽門輪より遠位の $1 \mathrm{~cm}$ 部で $25.7 \pm 0.3 \mathrm{pg} / \mathrm{mg}$ と急速に減少し, $2 \mathrm{~cm}, 3 \mathrm{~cm}$ 部の間に 差はみられず，それより遠位部ではさらに低値であっ た (Fig. 5).

(2) 粘膜内 gastrin 紐胞数

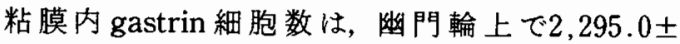
$410.4 / \mathrm{mm}^{2}$ と高値であったが, 幽門輪より遠位 $1 \mathrm{~cm}$ 部

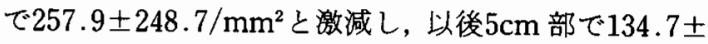
$65.9 / \mathrm{mm}^{2}, 10 \mathrm{~cm}$ 部 $136.0 \pm 51.2 / \mathrm{mm}^{2}$ と低値であった（Fig. 5).

2) Secretinの分布

(1) 粘膜内 secretin 含有量

粘膜内 secretin 含有量は幽門輪上では抽出できな

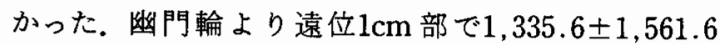
$\mathrm{pg} / \mathrm{mg}$ と比較的低值であったが, $2 \mathrm{~cm}$ 部より $10 \mathrm{~cm}$ 部 までは 3 倍強の高值がつづいた。それより遠位 $50 \mathrm{~cm}$ 部まで直線的に減少し， $50 \mathrm{~cm}$ 部での值は1,410.7士 $590.5 \mathrm{pg} / \mathrm{mg}$ と $1 \mathrm{~cm}$ 部の值と同程度であった. $50 \mathrm{~cm}$ 部より遠位ではさらに漸減し， $120 \mathrm{~cm}$ 部では $50.8 \pm$ $6.5 \mathrm{pg} / \mathrm{mg}$ ときわめて低値であった（Fig. 5).

(2) 粘膜内 secretin 細胞数

粘膜内 secretin 細胞数は，幽門輪上では認められな かったが，幽門輪より遠位1cm 部では384 $\mathrm{mm}^{2}$ とやや低值であったが, $2 \mathrm{~cm}$ 部より $10 \mathrm{~cm}$ 部まで は $2 \sim 3$ 倍の高値がつづき，それより遠位では $30 \mathrm{~cm}$ 部で $1 \mathrm{~cm}$ 部の值と同程度となり， $50 \mathrm{~cm}$ 部より遠位で はさらに漸減した（Fig. 5).
幽門輪より $1 \mathrm{~cm}$ と $3 \mathrm{~cm}$ 遠位部の標本で観察された secretin 細胞を200倍で検鏡したものでみてみると、染 色された secretin 細胞は幽門輪より遠位 $1 \mathrm{~cm}$ 部で少 ないのに対し， $3 \mathrm{~cm}$ 部では多数認められた（Fig. 6).

4. 剖検

温存手術を施行したすべてのイヌに剖検を行った が，胃空腸吻合部に漬瑒形成は認められず，胆管空腸 吻合部, 膵管空腸吻合部にも異常は認められなかった。 また，十二指腸温存範囲の大きさに関しても正確で あった。

\section{IV. 考 塞}

膵頭十二指腸切除は，1935年 Whipple ら ${ }^{1}$ が発表し て以来, 術式の改良工夫が行われ次第に広く施行され るようになり，わが国でも盛んに行われている。しか しWhippleの術式は, 術後に膵空腸吻合部の释合不全 や狭窄，逆流性胆管炎，消化管出血，胃空腸吻合部潰 瘍, 消化吸收障害などの合併症の発生が問題視されて いる.これらの合併症の 1 つである胃空腸吻合部潰瘍 の発生率は，膵頭十二指腸切除術施行例で $5 \sim 22 \%$,

膵全摘術例では8～60\%とさまざまな報告23324)29) 32) がある. 本邦に沶いては, 鈴木ら ${ }^{18)}$ が膵頭十二指腸切除 術および胨全摘術合わせて143例の吻合部潰瘍発生率 は4例2.7\%であったと報告している。

これに対して, 1978年 Traverso ら゙により考案され た温存術後の吻合部潰瘍の発生率は，0\%であったと 報告1013221)されている.しかし，この方法でも吻合部潰 痬の発生をみたとの報告11)15/23)24)市る。 Gebhardt ら ${ }^{15}$ ' 18 例中 7 例 (39\%) と高頻度の潰煌発生を報告し ているが，このような発生頻度の相違は術前の酸分泌 動態と十二指腸球部の温存範囲および再建術式が関与 
しているすのと思われる．吻合部潰場の成因を森本 ${ }^{33)}$ は央験的に全胃温存十二指腸切除術を施行し検討して いる。.それによると，吻合部潰場発生には高酸と膵液， 胆汁による中和が関係して招り，その予防には酸分泌 を抑制する胃切除術か迷走神経切離術（迷切術）ある いはそれらの併用などを選択し，さらに膵液，胆汁に よる中和が適確に行われる Billroth-I 法を選ぶことな どの配慮が望ましいと述へてている，そこで著者は実験 的に胃十二指腸球部温存 $(1 \mathrm{~cm}, 2 \mathrm{~cm}, 3 \mathrm{~cm})$ 十二指腸 切除術を施行し，吻合部潰瘍の成因を追求すべく胃内 外分泌に対する影響を検討した。 その結果, BAO は術 後 $1 \mathrm{~cm}$ 群および $2 \mathrm{~cm}$ 群で増加したが, $3 \mathrm{~cm}$ 群では術前 後ではとんど差が認められなかった。 また, MAOでは $1 \mathrm{~cm}$ 群で増加傾向 $(\mathrm{p}<0.1)$, IAO では $1 \mathrm{~cm}$ 群招よび $2 \mathrm{~cm}$ 群で有意 $(\mathrm{p}<0.01)$ に増加したが, $3 \mathrm{~cm}$ 群ではと もに術前後で汪とんど差が認められなかった. Brackney $ら^{34)}$ は，イヌに拈いて十二指腸切除前後の酸分泌 を Heidenhain pouch を用いて測定し，切除後に酸分 泌が亢進したと述べ，さらにQuintana ら ${ }^{35)}$, Konturek ら ${ }^{36}$ 的十二指腸切除後に胃酸分泌が元進したと報 告している。しかし, 著者の実験成績で十二指腸球部 の温存範囲を $3 \mathrm{~cm}$ にすると術前と同程度の酸分泌動 態を示したことから，この部に酸分泌抑制因子が存在 することは明らかである。

Andersson $^{37}$ ) は，十二指腸の口側，主として球部か ら, 空腹時でも, 食慨刺激時でも, その内腔の $\mathrm{pH}$ の低 下により胃酸分泌抑制因子が放出されると報告してい る. 胃酸分泌抑制因子としては secretin と gastric inhibitory polypeptide (GIP) ホルモンとが考党られ る. 著者は, このうちの secretin の分泌動態について 検討した。これは，胃酸分必元進にもとづく十二指腸 内の酸性化にともない，十二指腸粘膜より血中に放出 され，膵上りの重炭酸の外分泌を促進して十二指腸内 の中和をはかり，胃に対しては somatostatin および gastrin 細胞を介して酸分泌を抑制する生理作用を持 つからである.著者の実験で, BS は術後 $1 \mathrm{~cm}$ 群で有意 $(\mathrm{p}<0.01)$ に増加しており， secretin反応である $\mathrm{T}$. ISR, I-ISR もともに増加し, ことにI-ISR は有意 $(\mathrm{p}<$ 0.01）の増加であった。これは，ヒトの膵全摘術や膵 頭十二指腸切除後の残存空腸に塩酸負荷試験を行い, 血中 secretin が増加することより残存空腸にも酸に 反応する secretin 細胞が存在するとの報告 ${ }^{38) ~ 40) か ら ， ~}$ $1 \mathrm{~cm}$ 群でみられた酸分泌充進により残存 secretin 細 胞が過剩に反応したものと考えられる。また， $2 \mathrm{~cm}$ 群
および $3 \mathrm{~cm}$ 群では術後 BS は有意 $(\mathrm{p}<0.01)$ 飞減少 し, secretin 分泌反応は術前後で汪とんぞ差が認めら れなかった。すなわら，幽門輪より $2 \mathrm{~cm}$ 以上球部を温 存した場合は酸分泌量の減少にともなう negative feedback 機構によりBSが減少し, secretin 分泌反応 は術前後で差がなくなるものと思われる。一方, 酸分 泌を亢進させる作用のある血清 gastrin について検討 してみると, 森本 ${ }^{33}$ は血清 gastrin 值は十二指腸切除 前後で絶食時および食慨刺激時のいずれの場合でも明 らかな増減を認めて捛らず, 胃酸分泌の克進は血清 gastrinによるものではないと述べている。 また，金 はイヌに膵全摘とともに幽門輪より肛側約 $3 \sim 4 \mathrm{~cm}$ から Treitz 勒帯直下までの十二指腸を切除する幽門 輪・十二指腸球部温存膵十二指腸切除に扎いて, BAO は六進しているのに gastrin は低下していて両者間の feedback 機構が維持されていることを想定している. しかし, 著者の成績では, BG は術後すべての群で増加 しており, 特に $1 \mathrm{~cm}$ 群と $3 \mathrm{~cm}$ 群では有意 $(\mathbf{p}<0.01)$ K 増加した。また，刺激反応でみてみると，T-IGR は術 後 $1 \mathrm{~cm}$ 群で有意 $(\mathrm{p}<0.01)$ に増加し, $2 \mathrm{~cm}$ 群および 3 $\mathrm{cm}$ 群でも増加したがともに有意差は認められなかっ た. I-IGRは, 術後 $1 \mathrm{~cm}$ 群で増加傾向 $(\mathrm{p}<0.1), 2 \mathrm{~cm}$ 群で有意 $(\mathrm{p}<0.05)$ に増加, $3 \mathrm{~cm}$ 群においては術前後 でほとんど差が認められなかった。著者の実験では, gastrin 分泌反応は, $1 \mathrm{~cm}$ 群で術後增加し, $3 \mathrm{~cm}$ 群では 術前後で差がほとんど認められず，各群での胃酸分泌 動態と平行していた。このことから，十二指腸球部の 温存範囲が少ない場合は，十二指腸から放出される酸 分泌抑制因子の絶対量の低下によって, gastrin が増加 し酸分泌六進につながることが示啳された。 以上のよ らな球部温存 $1 \mathrm{~cm}$ 群と $3 \mathrm{~cm}$ 群の胃内外分泌面に及ぼ す影響の著明な羑の根拠を証明するため，著者は gastrin 拉よび secretin の十二指腸，小腸粘膜内分布を検 討した. gastrin は幽門輪には多く分布するが $1 \mathrm{~cm}, 2$ $\mathrm{cm}, 3 \mathrm{~cm}$ 遠位部粘膜内には漂とんど分布して淤ず， かつ各部位間で差が認められなかった。したがって， gastrin は球部温存範囲の大小にかかわらず, 術後内外 分泌機能には直接影響を与えていないと考えられる。 一方, secretin は幽門輪より $1 \mathrm{~cm}$ 遠位まではそれはぞ 多く分布して抢らず， $2 \mathrm{~cm}$ 遠位から急激に増加し，そ のピークは $10 \mathrm{~cm}$ 遠位まで続き，それより遠位では漸 減していた。 Cheyら ${ }^{42)}$ はイヌとヒトで secretin 細胞 を間接的螢光抗体法により組織学的検索を行い, 十二 指腸から回腸まで存在していることを確認しており, 
Larsson ら ${ }^{43)}$ も同じょうな報告をしている.さらに Polak $5^{44}$ は, secretin 細胞は十二指腸球部に高濃度 に分布し, 空腸上部にも存在しているが, 空腸下部に いくにしたがい密度を減じていると報告しており， Friedman ら ${ }^{45)}$ 同じような所見を述べている，黒川 $5^{46)}$ は, ヒトの十二指腸球部 secretin 細胞数と, 十二 指腸下行脚の secretin 細胞数について調べて, 粘膜中 secretin 含有量と平行し球部に多く, 下行脚に少く存 在すると報告しており，著者もこれらの報告とほぼ同 じような成績を得た。

以上の成績から, 球部温存 $1 \mathrm{~cm}$ 群, $2 \mathrm{~cm}$ 群の酸分泌 増加は十二指腸切除による duodenal brake の破綻に より生じることが示唆され, 球部温存 $3 \mathrm{~cm}$ 群では, 生 理的な胃内外分泌動態を示した。したがって，胃十二 指腸球部温存脺十二指腸切除は，酸分泌抑制因子であ る secretin 細胞が最も多く存在する幽門輪から $3 \mathrm{~cm}$ 遠位までの十二指腸球部を温存することにより, 術後, 術前と同しょうな生理的分泌機構が維持され，吻合部 潰瘍の発生を十分予防することが可能であることがわ かった.

本論文の要旨は, 第 5, 6 回消化器葴器相関研究会 (1987, 1988), 第31回日本消化器外科学会総会(1988), 第20,21回 胃分泌研究会 (1988，1989), 第89回日本外科学会総会 (1989), 第11回消化管ホルモン研究会 (1989), 第12回日本 膵切研究会（1989）に打いて発表した。

稿を終えるにあたり、ご指導, 御校閲を賜わった楖原宣教 授, 終始ご指導, 御鞭撻をいただいた順天堂大学伊豆長岡病 院外科渡部洋三教授, ならびに佐々木浩博士に深甚なる謝 意を表するととるにご協力下さった 308 研究室各位ならび に動物実験室, 共同生化研究室, 共同病理研究室の各位に感 謝する. また，貴重な secretin 抗血清を提供していただいた 国立がんセンター病院阿部蒸副院長, 細胞増殖因子研究部 山口建博士に深謝する。

\section{文 献}

1) Whipple AO, Parsons WB, Mullins CR: Treatment of carcinoma of the ampulla of Vater. Ann Surg $102: 763-779,1935$

2) Brunschwig A: Resection of head of pancreas and duodenum for carcinoma-Pancreatoduodenectomy. Surg Gynecol Obstet $65: 681-684$, 1937

3) Whipple AO: The rationale of radical surgery for cancer of the pancreas and ampullary region. Ann Surg $114: 612-615,1941$

4）竹下八洲男, 片山宽次, 関野秀継深か：膵頭十二指 腸切除後の消化性溲瘍の検討. 腹部救急訩療の進
歩 $3: 437-440,1984$

5）小笠原敬三, 吉村玄浩, 田野龍介ほか：膵頭十二指 腸切除術合併症の検討。倉敷中病年報 $54: 113$ $-121,1985$

6) Warren $\mathrm{KW}$ : Surgical management of chronic relapsing pancreatitis. Am J Surg 117 : 24-32, 1969

7) Traverso LW, Longmire WP: Preservation of the pylorus in pancreaticoduodenectomy. Surg Gynecol Obstet 146: 959-962, 1978

8) Traverso LW, Longmire WP: Preservation of the pylorus in pancreaticoduodenectomy-a follow-up evaluation. Ann Surg 192 : 306-310, 1980

9) Braasch JW, Gongliang J, Rossi RL: Pancreatoduodenectomy with preservation of the pylorus. World J Surg $8: 900-905,1984$

10) Grace PA, Pitt HA, Tompkins RK et al: Decreased morbidity and mortality after pancreatoduodenectomy. Am J Surg $151: 141$ $-149,1986$

11) Braasch JW, Rossi RL, Watkins E et al: Pyloric and gastric preserving pancreatic resection-experience with 87 patients. Ann Surg $204: 411-417,1986$

12) Warshaw AL, Torchiana DL: Delayed gastric emptying after pylorus-preserving pancreaticoduodenectomy. Surg Gynecol Obstet $160: 1-4,1985$

13) Pearlman NW, Stiegmann GV, Ahnen DJ et al : Acid and gastrin levels following pyloricpreserving pancreaticoduodenectomy. Arch Surg 121: 661-664, 1986

14) Grace PA, Pitt HA, Longmire WP: Pancreatoduodenectomy with pylorus preservation for adenocarcinoma of the head of the pancreas. Br J Surg $73: 647-650,1986$

15) Gebhardt V Ch, Gall FP, Rösch $W$ et al: Anastomosenulkus nach Whipplescher Operation mit Magenerhaltung. $\mathrm{Zbl}$ Chir 107:952 $-958,1982$

16) Newman KD, Braasch JW, Rossi RL et al: Pyloric and gastric preservation with pancreaticoduodenectomy. Am J Surg 145:152 $-156,1983$

17) Kamal MF, Itani , Coleman RE, et al: Pylorus-preserving pancreatoduodenectomy-a clinical and physiologic Appraisal. Ann Surg $204: 655-664,1986$

18）鈴木 敞, 金 輝次, 塩田昌明注か：胃十二指腸球 部温存膵十二指腸切除. 消外 $10: 339-352,1987$

19) Kim Hwi-Cha, Suzuki $T$, Kajiwara $T$ et al: 
Exocrine and endocrine stomach after gastrobulbur preserving pancmeatoduodenectomy. Ann Surg 206: 717-727, 1987

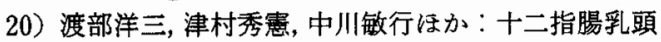
部癌に対する選択的近位迷走神経切離術 (SPV) 兼 全胃温存膵十二指腸切除術. 消外 $12: 227-233$, 1989

21) Cooper MJ, Williamson RCN : Conservative pancreatectomy. Br J Surg $72: 801-803,1985$

22）高田忠敬, 安田秀喜, 内山勝弘ほか：術後消化機能 からみた膵頭十二指腸切除後の再建法の検討一特 に全胃温存術式の位置づけ, 日消外会誌 $20: 930$ $-933,1987$

23) Crist DW, Sitzmann JV, Cameron JL: Improved hospital morbidity, and survival after the Whipple Procedure. Ann Surg 206:358 $-365,1987$

24) McAfee MK, van Heerden JA, Adson MA : Is proximal pancreatoduodenectomy with pyloric preservation superior to total pancreatectomy? Surgery $105: 347-351,1989$

25) Berson SA, Yallow RS: Nature of immunoreactive gastrin extracted from tissues of gastrointestinal tract. Gastroenterology $60: 215$ $-222,1971$

26) Straus E, Yallow RS: Immunoreactive secretin in gastrointestinal mucosa of several mammalian species. Gastroenterology $75: 401$ $-404,1978$

27）山口 建, 阿部 薰, 膳所富士男ほか：血中セクレ チンの Radioimmunoassay。治療 $58: 1513$ $-1520,1976$

28）高橋忠雄, 島津久明, 谷 昌尚汪か：イ邓の胃十二 指晹粘膜におけるガストリン細胞分布の定量的評 価. 日消病会誌 $74: 1362-1369,1977$

29) Scott HW, Dean RH, Parker T et al: The role of vagotomy in pancreaticoduodenectomy. Ann Surg $191: 688-696,1980$

30) Grant CS, Van Heerden JA: Anastomotic ulceration following subtotal and total pancreatectomy. Ann Surg $190: 1-5,1979$

31) McConnell DB, Sasaki TM, Garnjobst $W$ et al: Experience with total pancreatectomy. Am J Surg 139:646-649, 1980

32) Warren KW, Poulantzas JK, Kune GA: Life after total pancreatectomy for chronic pancreatitis : clinical study of eight cases. Ann Surg $164: 830-834,1966$

33）森本洋一：十二指腸切除の胃酸分泌, 血清 gas- trin, 血清 secretinに及ぼす影響と, 膵液, 胆汁の 吻合部漬瘍に対する抑制効果の実験的検討. 日消 外会誌 $18: 1609-1619,1985$

34) Brackney EL, Thal AP, Wangensteen OH: Role of duodenum in the control of gastric secretion. Proc Soc Exp Biol Med 88:302 $-306,1955$

35) Quintana R, Kohatzu S, Woodward ER et al: Mechanism of duodenal inhibition of gastric secretion. Arch Surg 89 : 585-591, 1964

36) Konturek S, Grossman MI: Localization of the mechanism for inhibition of gastric secretion by acid in intestine. Gastroenterology 49 : 74-78, 1965

37) Andersson S: Inhibitory mechanisms in duodenal control of gastric acid secretion. Gastroenterology 61 : 778-780, 1971

38) Hanssen LE, Kåresen $R$, Aune $S$ : Immunoreactive secretin release in patients after duodenectomy and partial or total pancreatectomy. Scand J Gastroenterol 14:997 $-1000,1979$

39）山崎軍治, 黒田吉隆, 竹下八洲男ほか：腈頭十二指 腸切除後の内因性セクレチン分泌。臨外 36 ： 1131-1135, 1981

40）西脇英樹，佐竹克介，梅山 馨：血浆セクレチン分 泌動態上り久た胃切除および膵頭十二指腸切除後 の病態. 日外会誌 $86: 1173-1175,1985$

41）金 輝次：胃温存膵十二指腸切除後の胃内外分泌 に関する実験的ならびに臨床的研究. 日外宝 $55: 314-333,1986$

42) Chey WY, Escoffery R: Secretin cells in the gastrointestinal tract. Endocrinology 98 : 1390-1395, 1976

43) Larsson L-I, Sundler F, Alumets J et al: Distribution, ontogeny and ultrastructure of the mammalian secretin cell. Cell Tiss Res 181 : 361-368, 1977

44) Polak JM, Bloom S, Pearse AGE: Immunofluorescent localization of secretin and enteroglucagon in human intestinal mucosa. Scand J Gastroenterol 6 : 739-744, 1971

45) Friedman MHF, Thomas JE: The assay and distribution of secretin. J Lab Clin Med 35 : 366-372, 1950

46）黑川正典, 待井隆志, 井上忠昭ほか：十二指腸溃場 に拈けるセクレチン分泌動態。消化管ホルモン研 究会編。消化管ホルモン (II). 医学図書出版, 東 京, 1982, p58-64 


\title{
Experimental Studies on the Gastric Functions of Exocrine and Endocrine System after Duodenectomy with Preservation of the Stomach and Duodenal Bulb
}

\author{
Seiichi Ono \\ The First Department of Surgery, Juntendo University School of Medicine \\ (Director: Prof. Noburu Sakakibara)
}

In order to elucidate the cause of stomal ulcer, one of the complications associated with pancreatoduodenectomy, an investiagation was experimentally carried out to determine the relationship of exo- and endocrine gastric functions to the extent of preservation of the duodenal bulb after duodenectomy with preservation of the stomach and the duodenal bulb (preservative surgery). After the preservative surgery, the basal acid output, maximum acid output and insulin acid output were markedly increased, by $216.7 \%, 50.3 \%$ and $108.5 \%$, respectively, when $1 \mathrm{~cm}$ of the duodenal bulb was preserved, while when $3 \mathrm{~cm}$ of the duodenal bulb was preserved, the changes were negligible, $5.5 \%, 3.0 \%$ and $1.9 \%$, respectively, that is, as the extent of preservation of the duodenal bulb increased, the rate of increase in gastric acid secretion decreased. Secretin was present in a high concentration in the distal part 2 to $10 \mathrm{~cm}$ removed from the pyloric ring. These findings suggest that the postoperative increase in gastric acid secretion as due to the disruption of the duodenal brake. Further more, when $3 \mathrm{~cm}$ of the duodenal bulb was preserved, functions of physiological exo- and endocrine gastric secretion were retained. This finding indicates that the occurrence of postoperative stomal ulcers can be prevented by preserving the duodenal bulb to this extent.

Reprint requests: Seiichi Ono The First Department of Surgery, Juntendo University School of Medicine 2-1-1 Hongo, Bunkyo-ku, Tokyo, 113 JAPAN 